\title{
Highlights on Geochemical Changes in Archaean Granitoids and Their Implications for Early Earth Geodynamics
}

\author{
Jaana Halla \\ Natural Sciences Unit, Finnish Museum of Natural History, University of Helsinki, P.O. Box 44, 00014 Helsinki, \\ Finland; jaana.halla@helsinki.fi; Tel.: +358-50-3462721
}

Received: 17 August 2018; Accepted: 11 September 2018; Published: 17 September 2018

\begin{abstract}
The Archaean (4.0-2.5 Ga) continental crust is mainly composed of granitoids, whose geochemical characteristics are a function of their formation mechanisms and components, as well as physical conditions of their source. Therefore, revealing changes in Archaean geodynamic processes requires understanding of geochemical changes in Archaean granitoids. This paper compares key geochemical signatures in granitoid occurrences from the Eoarchaean to Neoarchaean Eras and aims to highlight changes or variations in their geochemical signatures. The study is performed by exploring and comparing geochemical and geochronological datasets of Archaean granitoids compiled from literature. The results show that two end-members of sodic TTGs (tonalite-trondhjemite-granodiorite) occur throughout the Archaean: low- and high-HREE (heavy rare earth elements) types. A profound change in granitoid geochemistry occurred between 3.0 and $2.5 \mathrm{Ga}$ when multi-source high-K calc-alkaline granitoid batholiths emerged, possibly indicating the onset of modern-type plate tectonics.
\end{abstract}

Keywords: Eoarchaean; Paleoarchaean; Mesoarchaean; Neoarchaean; Archaean geochemistry; granitoids; TTG; sanukitoids; Archaean geodynamics; origin of continents

\section{Introduction}

It is well known that continents, now covering one-third of the Earth's surface, have grown through time. However, the exact nature and timing of the Earth's geodynamic changes that transformed the Hadean magma ocean to the large landmasses that rose above the sea level and attracted life are still unclear. Geochemical characteristics of granitoids, of which the continental crust is mainly composed, are a function of their formation mechanisms and components, as well as physical conditions of their source and, therefore, can give clues on the growth mechanisms of continents.

Granitoids from the fragments of the earliest Archaean continental crust have different appearance and geochemical features from the diversified, multi-source granitoid batholiths of the present-day continents. The early evolution of continents is characterized by formation of large volumes of sodic TTG (tonalite-trondhjemite-granodiorite) granitoids from basaltic precursors. The models presented to explain the formation of TTGs include stagnant lid (single plate) tectonics, plume tectonics involving mantle upwelling, or arc tectonics related to subduction, which all may cause episodic melting of basaltic precursors [1,2]. At 3.0-2.5 Ga, there was a significant change in the Earth's geodynamics indicated by the emergence of multi-source high-K calc-alkaline granitoid batholiths, which has been related to increasing crust-mantle interactions due to the onset of modern-type plate tectonics [3-5].

It is clear that geochemistry alone cannot distinguish between geodynamic models for the earliest crust. However, there are some critical geochemical questions that should be resolved before a thorough understanding of Earth's early evolution can be achieved. The aim of this paper is to bring out these 
questions by exploring key geochemical features of the most recent, methodologically up-to-date, and comparable datasets of Archaean granitoids available in the literature.

The purpose of this paper is to highlight geochemical changes in the Archaean by comparing critical element compositions of selected representatives of different types of granitoids from Eoarchaean with the Archaean-Proterozoic boundary. Especially important are the contents of (1) mantle compatible elements $\mathrm{Mg}, \mathrm{Cr}$, and $\mathrm{Ni}$; (2) garnet compatible trace elements $\mathrm{Y}$ and HREE; and (3) incompatible elements $\mathrm{K}, \mathrm{Ba}$, Sr, and LREE (light rare earth elements). Geochemical features of granitoids can be expressed as signatures, combinations of element characteristics that can be related to the sources of granitoids. In order to facilitate the comparisons presented in this paper, the geochemical characteristics of granitoids are described in terms of geochemical signatures or fingerprints that can be addressed to their possible sources, as explained next.

A 'mantle signature' can be observed in directly mantle-derived granitoids that show lower $\mathrm{SiO}_{2}$ contents and high contents of mantle compatible elements $\mathrm{Mg}, \mathrm{Cr}$, and $\mathrm{Ni}$, whereas granitoids derived from basaltic precursors show higher $\mathrm{SiO}_{2}$ contents and low mantle compatible elements, that is, they show a 'basaltic crust signature'. An Archaean mantle overprinted by crust-mantle interactions may carry a specific 'enriched mantle signature' (high Mg-K-Ba-Sr-P and LREE), which is a typical feature of sanukitoid granitoids. This signature cannot be a consequence of fractional crystallization, because it is independent of the $\mathrm{SiO}_{2}$ content and can be also found in mafic rocks, such as lamprophyres, which are often associated with sanukitoids.

Granitoids derived from garnet-bearing sources, where garnet is retained in the residue (e.g., deep lower crust), show low $\mathrm{Y}$ and HREE, a signature that is termed hereafter the 'garnet fingerprint'. Continental crust-derived granitoids show variable geochemical fingerprints reflecting the heterogeneity of their source, but in general, their $\mathrm{SiO}_{2}$ and $\mathrm{K}_{2} \mathrm{O}$ contents are high and the mantle and enriched mantle signatures are absent, characteristics that are hereafter termed as the 'crustal signature'.

This paper follows a rough classification into sodic TTGs (tonalite-trondhjemite-granodiorite) with low- and high-HREE end-members and high-K calc-alkaline granitoids, and the division of the latter into two groups by their main geochemical features: the silica and $\mathrm{Mg}$ content [3]. The first group includes low-silica-high-Mg granitoids such as sanukitoids (granitoids with high K-Ba-Sr-P and LREE) pointing to a contribution from a mantle source. The second group consists of high-silica -low-Mg granitoids, the origin of which can be related purely to the melting of pre-existing continental crust. For further background information on Archaean granitoids, the reader is referred to recent literature on the nomenclature, classifications, and main geochemical features of Archaean granitoids [4-6].

A global and secular approach instead of individual craton or terrain analysis is selected for the study, because at the times when a granitoid was formed, the present cratons and terrains did not exist or were not at their current positions or configurations. Ancient terrains assembled, broke apart, and drifted around the globe as a result of plate tectonic processes. A craton analysis would require larger and more complete and coherent datasets than available at present.

\section{Datasets}

Major well-preserved Eoarchaean to Neoarchaean occurrences of granitoid complexes, from which recent geochronological and geochemical datasets are available in the literature, are selected for the study. The major and trace element data and $\mathrm{U}-\mathrm{Pb}$ zircon ages for representative samples and averages are presented in Supplementary Table S1.

The oldest Eoarchaean (4.0-3.6 Ga) datasets are selected from the Acasta Gneiss Complex (4.02-2.9 Ga) of the Slave Province in the Canadian Shield [7]. The other Eoarchaean samples are from the largest Eoarchaean crustal fragment, the Itsaq Gneiss Complex (3.89-3.65 Ga) in southern West Greenland [8], and the Anshan Complex (3.81-3.13 Ga) of the North China Craton [9].

Paleoarchaean (3.6-3.2 Ga) datasets are from the Ancient Gneiss Complex of Swaziland (3.5-3.4 Ga) in the eastern Kaapvaal Craton in southern Africa [10] and the Singhbhum Craton 
(3.5-3.2 Ga) in eastern India [11]. These cratons are selected for the study because they both indicate an appearance of a new type of magmatism in the Paleoarchaean.

Mesoarchaean $(3.2-2.8 \mathrm{Ga})$ TTG $(3.0 \mathrm{Ga})$ and sanukitoid $(2.87 \mathrm{Ga})$ datasets are from the Yangtze block, South China [12] and Carajás Province, Amazonian Craton, South-America [13], respectively. When Yangtze block represents classical TTGs, the Carajás province indicates an emergence of a completely new type of Archaean granitoids.

Neoarchaean $(2.8-2.5 \mathrm{Ga}$ ) data is represented by averages based on a dataset of 295 samples of 2.9 to $2.7 \mathrm{Ga}$ juvenile granitoids from granite-greenstone terrains in the western parts of the Archaean Karelian and Kola cratons of the Fennoscandian Shield. The averages are calculated for three distinct geochemical groups: (1) low-HREE TTGs (80 samples with high $\mathrm{SiO}_{2}$, low $\mathrm{Mg}$, and low HREE), (2) high-HREE TTGs (45 samples with slightly lower $\mathrm{SiO}_{2}$, higher $\mathrm{MgO}, \mathrm{Cr}$, and $\mathrm{Ni}$, and high $\mathrm{HREE}$ ), and (3) high Ba-Sr sanukitoid granitoids (170 samples with lower silica, medium-HREE, high Mg, and high K-Ba-Sr). More details on the Fennoscandian Neoarchaean averages can be found in the literature [14].

\section{Bar Diagrams}

The bar diagrams are selected to best illustrate the comparisons of major and trace element contents, because, unlike in the case of traditional spider and REE (rare earth elements) diagrams, the silica content can be plotted in the same diagram. Therefore, samples with similar silica contents can be selected for plotting, and thus are comparable with respect to their other element contents.

To reveal the differences between the Archaean and modern continental crust, the data are normalized to the present-day average upper crust value of Rudnick and Gao [15]. In order to trace the temporal differences within the Archaean granitoids, the data are compared with Fennoscandian Neoarchaean reference averages for ca. 2.8 Ga high- and low-HREE TTGs and ca 2.7 Ga sanukitoids in bar diagramspresenting data from Eoarchaean, Paleoarchaean, and Mesoarchaean granitoids.

\subsection{Eoarchaean (4.0-3.6 Ga)}

Representative Eoarchaean TTG (tonalite-trondhjemite-granodiorite) samples of the Acasta, Itsaq, and Anshan complexes are selected for the bar graphs in Figure 1.

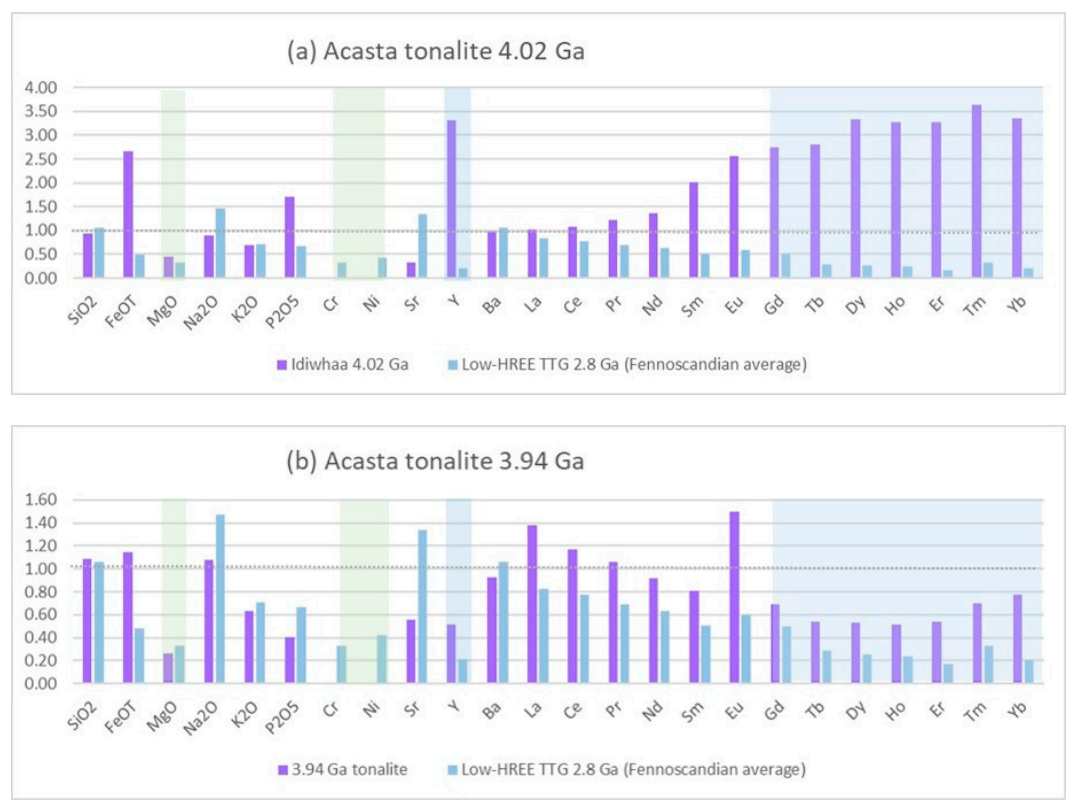

Figure 1. Cont. 


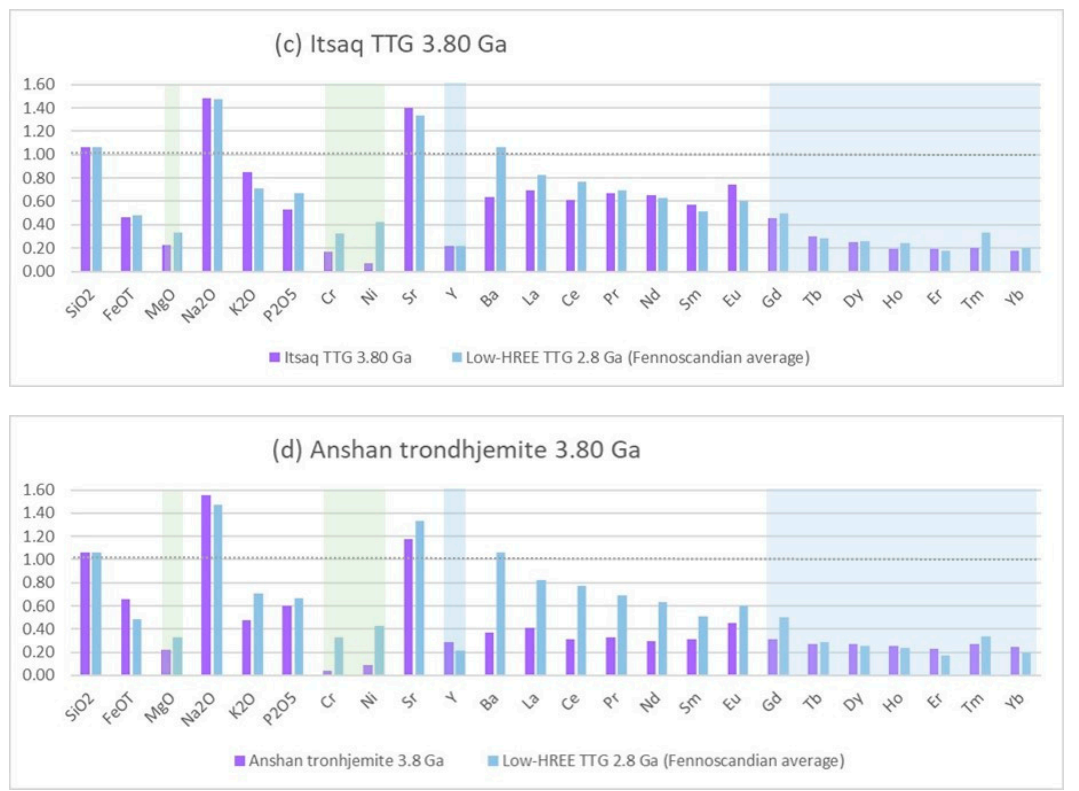

Figure 1. Bar graphs of the selected major and trace elements (Supplementary Table S1) of Eoarchaean (a) 4.02 Ga Idiwhaa tonalite (note the extended vertical scale due to high HREE contents), (b) 3.94 Ga tonalite from the Acasta Gneiss Complex, western Slave Province, Canada [7], (c) 3.8 Ga tonalite from the Itsaq Gneiss Complex in southern West Greenland [8], and (d) 3.81 Ga Anshan trondhjemitic gneiss from the Anshan Complex in the North China [9] normalized to the present-day average crust [15]. The Fennoscandian average for 2.8 Ga low-HREE tonalite-trondhjemite-granodiorite (TTG) [14] is presented for reference. Mantle compatible elements are indicated by green shading, and garnet-controlled elements by blue shading. The composition of present-day average upper continental crust is presented by a dashed line.

\subsubsection{Acasta Gneiss Complex, Slave Province}

The oldest granitoids dated by the U-Pb zircon method are found within the 4.02-2.90 Ga Acasta Gneiss Complex at the western margin of the Slave Province in the Northwest Territories of Canada. The oldest dated rock, the Idiwhaa tonalitic gneiss, is different from the 'classical' TTGs by showing lower $\mathrm{SiO}_{2}$ contents, high $\mathrm{FeO}$, and flat REE patterns with pronounced negative $\mathrm{Eu}$ anomalies and suggests an origin by shallow melting in a mafic source and subsequent fractional crystallization $[7,16,17]$.

Figure 1a,b compares the 4.02 Ga Idiwhaa tonalite (sample JR13-108) [7] and 3.94 Ga Acasta TTG (sample JR13-206) [7] with the 2.8 Ga Fennoscandian low-HREE TTG average. The bar diagram shows that the Idiwhaa tonalites (Figure 1a) lack both the mantle signature (i.e., show low $\mathrm{Mg}, \mathrm{Cr}$, and $\mathrm{Ni}$ ) and garnet fingerprint (i.e., show high $\mathrm{Y}$ and HREE) and have elevated total iron content, whereas the 3.94 Ga tonalite (Figure 1b) resemble the Fennoscandian low-HREE TTGs by showing the typical garnet fingerprint and lacking the mantle signature.

The geochemical characteristics of the Idiwhaa tonalite show some affinities to plagiogranites of the Oman ophiolites [18] and indicate melting of a basaltic source within oceanic crust that was not thick enough to stabilize garnet. The 3.94 TTGs, instead, indicate thickening of the basaltic crust and formation of a garnet-bearing lower crust source in plume-related oceanic plateaus or subduction-related island arcs. A special characteristic of the 3.94 TTGs is the high $\mathrm{Cu}$ content (seven times higher than that of the average upper crust), which is also typical for the Fennoscandian low-HREE TTGs (Table S1). This may be a sporadical feature related to VHMS (volcanic-hosted massive sulphide) deposits, however, pointing to oceanic crust origin. A prominent feature is very high $\mathrm{Zr}$ and $\mathrm{Hf}$ concentrations, as well as high $\mathrm{Nb}$ and $\mathrm{Ta}$ (Table S1). 


\subsubsection{Itsaq Gneiss Complex, West Greenland}

The Itsaq Gneiss Complex in southern West Greenland is one of the largest and best-preserved Eoarchaean TTG terrains. Comparison of the Itsaq 3.80 Ga TTG (sample JEH 10-25) [8] with the Neoarchaean low-HREE TTGs from Fennoscandia in Figure 1c illustrates the typical features of the Itsaq TTGs; the absence of the mantle signature and a prominent garnet fingerprint similar to that of Neoarchaean low-HREE TTGs.

Geochemical signatures of the Itsaq gneisses point to crust formation from thick basaltic precursors during the Eoarchaean, which is supported by the Hf isotope record from the Itsaq Gneiss Complex pointing to juvenile crustal formation [19].

The similarity of the Eoarchaean and Neoarchaean granitoid geochemistry indicates that comparable crust-forming processes converting thick basaltic crust to TTGs were prevailing, although episodically, from Eo- to Neoarchaean. It can be speculated that if this process was subduction, it would have resulted in more heterogeneous element compositions of granitoids due to crust-mantle recycling and contributions from enriched mantle sources. Distinguishing between stagnant lid, plume, and arc tectonics is not possible with the presented data.

\subsubsection{Anshan Complex, North China Craton}

The Anshan trondhjemitic gneisses are located in the North China Craton. The age of the selected sample (C209-8) [9] from a massive trondhjemitic gneiss is $3812 \pm 8 \mathrm{Ma}$. The Anshan trondhjemites are depleted in LILE (large ion lithophile elements, especially K and Ba) and LREE, compared with the Fennoscandian low-HREE TTGs and the Itsaq gneisses, and show high Nb and Ta contents (Table S1). The garnet fingerprint is clear and the mantle signature is absent.

\subsection{Paleoarchaean (3.6-3.2 Ga)}

To explore possible changes in granitoid geochemistry between Eo- and Paleoarchaean, different types of ca 3.5 Ga granitoids from the the Ancient Gneiss Complex (3.5-3.4 Ga) of Swaziland in the eastern Kaapvaal Craton in southern Africa and from the Singhbhum Craton (3.5-3.2 Ga) in eastern India are plotted on the bar diagrams. These are selected because recent papers $[10,11]$ have revealed the emergence of new rock types in the Paleoarchaean: diorites and granites, which have an important role in understanding the evolution of plate tectonics.

\subsubsection{Ancient Gneiss Complex of Swaziland}

The Ancient Gneiss Complex of Swaziland is comprised of two types of tonalitic rocks: (1) migmatitic and folded trondhjemitic TTG gneisses (3.7-3.2 Ga Ngwane TTGs) with amphibolite banding and (2) homogeneous calc-alkaline dioritic to tonalitic plutons intruded into the Ngwane TTGs at 3.48-3.43 Ga (Tsawela tonalite suite) [10].

The bar diagrams in Figure 2a plot the Ngwane TTG samples AGC470 (3.45 Ga) and AGC352 $(3.44 \mathrm{Ga})$ [8] along with the Fennoscandian high-HREE TTG average. Both samples lack the garnet fingerprint resembling the Neoarchaean high-HREE TTGs. The sample AGC470 has a slightly elevated mantle signature (compared with Eoarchaean) and very high $Y$ and LREE contents, similar to the Idiwhaa tonalites of the Acasta Gneiss Complex. Thus, the geochemical signatures of the Ngwane gneisses suggest a shallow oceanic crust source.

The Tsawela diorite AGC75 (3.48 Ga) show a clear mantle signature and enrichment in LREE compared with the Ngwane TTGs, which suggests a contribution from a shallow mantle source (Figure 2b). The Tsawela diorites confirm that mantle-derived low-K calc-alkaline granitoids were forming at least since Paleoarchaean, either by mixing with TTGs or by fractional crystallizaton of intermediate magma, possibly in plume-related processes [10]. The extent of Paleoarchaean dioritic magmatism remains to be defined in the future. 

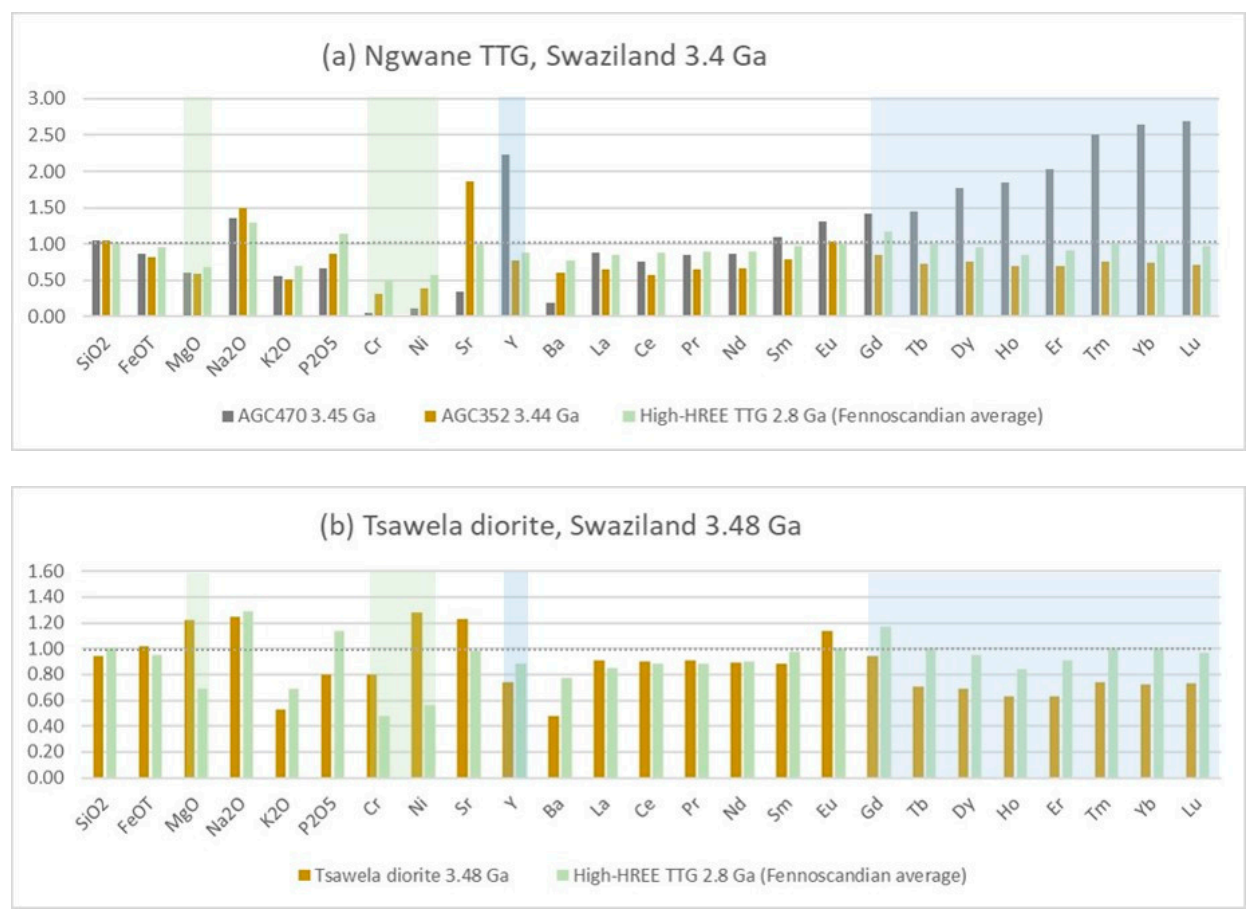

(c) Singhbhum TTG $3.5 \mathrm{Ga}$

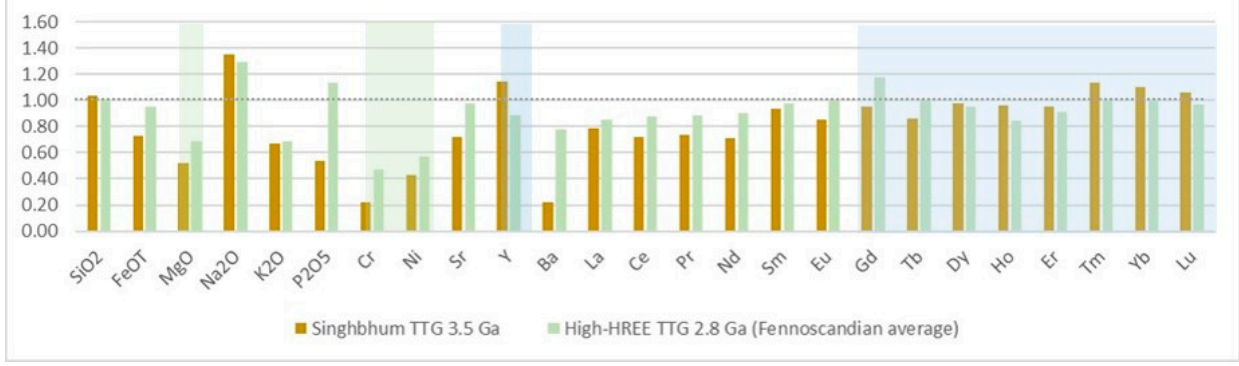

(d) Singhbhum granite $3.3 \mathrm{Ga}$

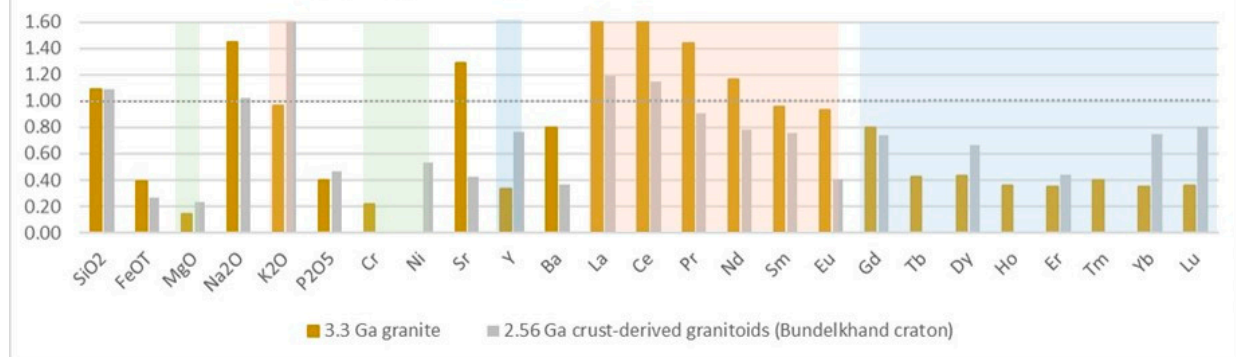

Figure 2. Bar graphs of the major and trace element data (Supplementary Table S1) of Paleoarchaean (a) Ngwane TTG (note the extended vertical scale due to high HREE contents); (b) Tsawela diorite from the Ancient Gneiss Complex of Swaziland, eastern Kaapvaal craton [10]; (c) TTGs; and (d) granitoids from the Singhbhum Craton, eastern India [11], normalized to the present-day average crust [15]. The Fennoscandian average for $2.8 \mathrm{Ga}$ high-HREE TTGs [14] or a representative composition of a 2.56 Ga crust-derived granitoid from the Bundelkhand Craton [3] is presented for reference. Mantle compatible elements are indicated by green shading, garnet-controlled elements by blue shading, and crustal elements by reddish shading. The composition of present-day average upper crust is presented by a dashed line. 


\subsubsection{Singhbhum Craton, Indian Shield}

Paleoarchaean 3.5 Ga TTGs and 3.3 Ga granites from the Singhbhum Craton in eastern India [11] are compared with the Fennoscandian Neoarchaean high-HREE TTGs in Figure 2c. The zircon $\mathrm{U}-\mathrm{Pb}$ record indicates three peaks in the juvenile crustal growth of the Singhbhum Craton: 3.53, 3.44 , and $3.38 \mathrm{Ga}$. These peaks coincide with regional peaks indicated by correlation analyses of Condie et al. [20].

The Singhbhum TTG (sample SG 131) [11] differs from the Fennoscandian low-HREE TTGs by the absence of the garnet fingerprint, which is clearly indicated by the high Y and HREE element contents, and slightly elevated mantle signature. The comparison in Figure 2c shows that the Singhbhum TTGs resamble the Fennoscandian Neoarchaean high-HREE TTGs.

The Singhbhum craton is intruded by voluminous high-K granitoids forming an extensive batholitic complex. Figure $2 \mathrm{~d}$ illustrates the main geochemical features of the granitoids (sample SBG41) [11]; the lack of the mantle signature and a clear garnet fingerprint, as well as the crustal signature (high $\mathrm{K}$ and LREE). These characteristics can be explained by remelting of pre-existing crustal lithologies. A notable feature is that the TTGs have higher Y and HREE contents than the granitoids. The data from the Singhbhum craton show clearly that intracrustal melting occurred in the Paleoarchaean.

\subsection{Mesoarchaean (3.2-2.8 Ga)}

\subsubsection{Yangtze Block, South China}

In South China, 3.0 Ga TTGs from the Kongling high-grade metamorphic terrane in the Yangtze block (sample SNJ10-18) [12] show geochemical features very similar to the Fennoscandian $2.8 \mathrm{Ga}$ low-HREE TTGs; the mantle signature is absent and the garnet fingerprint is prominent (Figure 3a). This indicates the development of thicker continental crust in the Mesoarchaean.

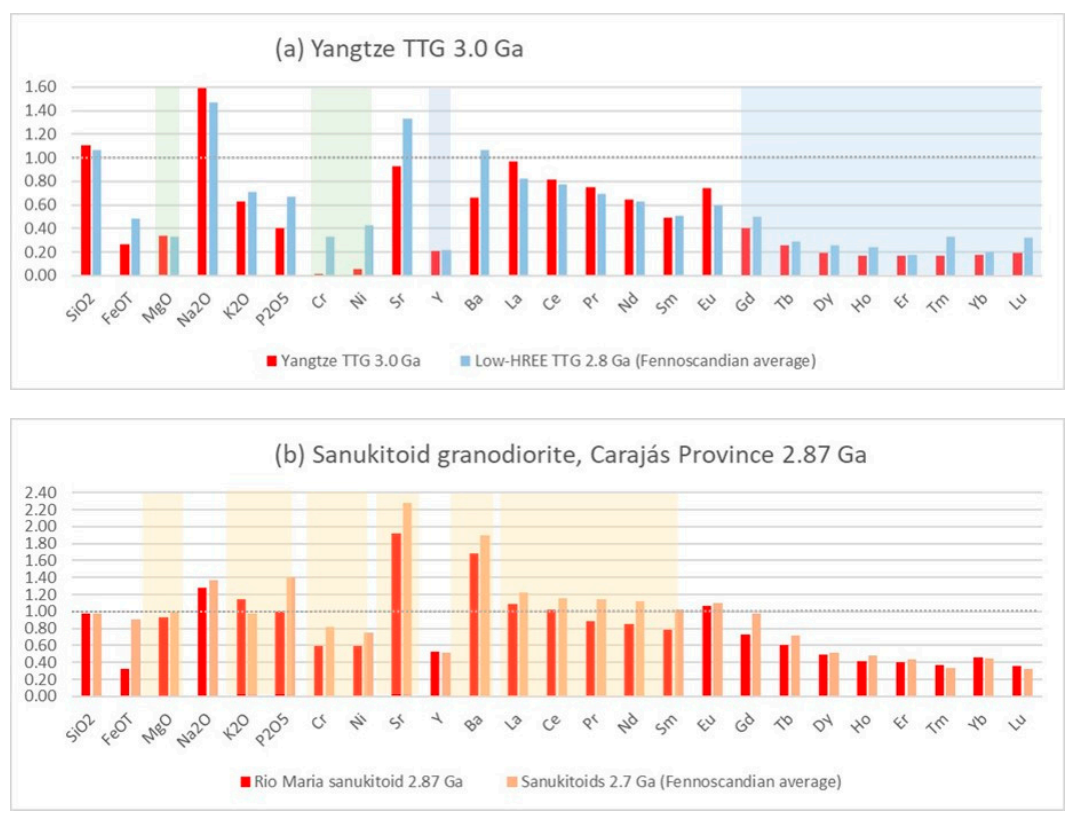

Figure 3. Bar graphs of the major and trace element data (Supplementary Table S1) of Mesoarchaean (a) TTG from the Yangtze block, North China Craton [12] and (b) sanukitoids from the Carajás Province, Amazonian Craton, South-America [13], normalized to the present-day average crust [15] (note the extended vertical scale due to high concentrations of $\mathrm{Ba}$ and $\mathrm{Sr}$ ). The Fennoscandian averages for 2.8 Ga high-HREE TTGs or 2.7 Ga sanukitoids are presented for reference [14]. Mantle compatible elements are indicated by green shading, garnet-controlled elements by blue shading, and the enriched mantle signature by yellow shading. 


\subsubsection{Sanukitoid granitoids, Carajas Province, Brazil}

Sanukitoid granitoids with mantle signature and high K-Ba-Sr-P and LREE characteristics appeared in the Archaean rock record in the Mesoarchaean. The oldest sanukitoids are found in the Pilbara [21] and Amazonian [13] cratons (at 2.95 Ga and $2.87 \mathrm{Ga}$, respectively). Figure 3b compares $2.87 \mathrm{Ga}$ sanukitoid granodiorites from the Carajás Province, Amazonian Craton, South America (sample MFR-111) [13] with the Fennoscandian Neoarchaean (2.7 Ga) sanukitoid average.

\subsection{Neoarchaean $(2.8-2.5 \mathrm{Ga})$}

The averages of two ca. 2.8 Ga TTG datasets and one ca. 2.7 Ga sanukitoid dataset from Karelia and Kola cratons of the Fennoscandian Shield, used for reference in this study, show that the Neoarchaean low-HREE TTGs carry a basaltic crust signature and a garnet fingerprint, but the mantle signature is absent. High HREE TTGs, on the contrary, show a variable mantle signature, but the garnet fingerprint is absent. The contrasting HREE contents have been explained by melting at different depths. The enriched mantle signature (high K-Mg-Ba-Sr-P and LREE) observed in sanukitoid granitoids is attributed to metasomatic processes that have affected the mantle before and during melting.

These characteristics may indicate a deep garnet-bearing basaltic source in a thickened crust for low-HREE TTGs, shallow garnet-free source and mantle interactions for the high-HREE TTGs, and an enriched mantle source for sanukitoids in the Neoarchaean.

\section{Discussion}

\subsection{Eoarchaean Melting within Oceanic Crust}

The Earth's earliest tonalites, represented by the 4.0 Ga Idiwhaa tonalites, lack the mantle geochemical signature and show high HREE contents suggesting shallow melting within Hadean oceanic crust at the Hadean-Eoarchaean boundary. These tonalites seem to resemble more present-day low-silica, high-Fe plagiogranites than the classical Archaean TTGs.

Eoarchaean Acasta $(3.94 \mathrm{Ga})$, Itsaq $(3.80 \mathrm{Ga})$, and Aishan $(3.80 \mathrm{Ga})$ tonalites and trondhjemites (Figure 1) represent the earliest low-HREE TTGs sensu stricto. They lack the mantle signature, which points to a derivation from basaltic precursors. The garnet fingerprint (low HREE and Y) appeared at $3.94 \mathrm{Ga}$ (and persisted to Neoarchaean), traditionally interpreted to indicate the thickening of the basaltic crustal sources for TTGs in plume-generated oceanic plateaus or subduction-related island arcs. However, the occurrence of the high-HREE type of TTGs sensu stricto in the Eoarchaean cannot be ruled out without further study.

The Eoarchaean TTGs may or may not show slightly enriched LREE and LILE characteristics, indicating possible variable contributions from small volumes of felsic crust. It seems that the mantle did not play an active role in the petrogenesis of Eoarchaean granitoids (except for the oldest ones); granitoids were formed by melting in the thick oceanic crust of basaltic composition. It would be attractive to speculate an Early Earth, the surface of which started to rift in many places because of the Late Heavy Bombardment or plume activity, producing large amounts of basaltic magmas, which, in turn, remelted to produce tonalites.

\subsection{Paleoarchaean Thickening of the Continental Crust}

Paleoarchaean formation of high-HREE types of TTGs seems to be common, as indicated, for example, by the data from the Kaapvaal and Singhbhum (Figure 2) cratons. However, both low- and high-HREE types have been observed to occur even within the same complex [22].

Also, new types of rocks appeared in the Paleoarchaean; the calc-alkaline plutons from mantle sources (e.g., $3.45 \mathrm{Ga}$ low-K calc-alkaline diorites of Swaziland) and crust-derived granites (e.g., the $3.3 \mathrm{Ga}$ Singhbhum crust-derived granitoids and the $3.3 \mathrm{Ga}$ Wyoming calc-alkaline granitoids [23]). The appearance of large pure crust-derived granite batholiths indicates that in 
the Paleoarchaean, continents were thick enough for crustal antexis to occur. The tectonics setting, subduction versus plume, is still under debate. However, high-K granitoids showing an enriched mantle signature that could be unequivocally linked to convergent continental margins have not yet been observed to occur in the Paleoarchaean.

\subsection{Meso-to Neoarchaean Geodynamic Change}

The appearance of sanukitoids carrying an enriched mantle signature (high $\mathrm{K}-\mathrm{Mg}$-Ba-Sr-P) in the Mesoarchaean may be related to the onset of modern-style plate tectonics. The enrichment of the subcontinental lithospheric mantle wedge with incompatible elements requires the recycling of material into the mantle, which, in turn, is a process generally attributed to subduction. Because TTGs and sanukitoids are not temporally related-they show local time gaps of variable lengths [4] - the petrogenesis by direct mixing of mantle and TTG melts can be ruled out. The origin of sanukitoids has been related to melting in a mantle wedge metasomatized by subduction-related fluids. The possible geodynamic processes behind the formation of sanukitoids are slab breakoff, delamination, slab rollback, or other tensional processes at convergent continental margins.

There was a long period from Eoarchaean to Neoarchaean when episodic TTG magmatism was dominant. This period was followed by a relatively short period of sanukitoid magmatism and coeval or subsequent crust-derived magmatism. Locally, sanukitoids were intruded after the latest phase of TTG magmatism in the area. The local time gaps between TTG and sanukitoid formation vary up to $150 \mathrm{Ma}$. The temporal relationships between sanukitoid and TTG magmatism are illustrated in the literature [4] (Figure 3b). An important phenomenon is that, locally, major TTG formation ceased after the appearance of sanukitoids. In each craton, the change from sodic TTG magmatism to sanukitoid and coeval or subsequent high-K crust-derived magmatism occurred at different times between 3.0 and $2.5 \mathrm{Ga}$.

Since their appearance in the Archaean rock record at around $3.0 \mathrm{Ga}$, sanukitoids continued to form progressively from craton to craton until the end of the Archaean. The oldest, Mesoarchaean sanukitoids, were formed in the Pilbara (west Australia) and Amazonian (Carajás Province, South America) cratons. In the Neoarchaean, the formation of sanukitoids was a spatially and temporally progressive process. The process started in the Murchison Province of the western Yilgarn Craton (west Australia) (2.76 Ga); continued in the eastern part of the Karelian Craton $(2.74 \mathrm{Ga})$; and advanced to West Karelia $(2.72 \mathrm{Ga})$, northern Superior $(2.70 \mathrm{Ga})$, southern Superior $(2.68 \mathrm{Ga})$, and eastern Yilgarn Craton $(2.66 \mathrm{Ga})$. The latest sanukitoids were formed between 2.6 and $2.5 \mathrm{Ga}$ in central India and north China [4]. It seems that the formation of sanukitoids was a temporally restricted and spatially and temporally progressive event signifying an emergence of new geodynamic processes developing between 3.0-2.5 Ga. Many researchers have recognized this geodynamic change [2,4].

\subsection{Neoarchaean Diversification of Granitoids}

The geochemical changes that started in the Mesoarchaean [13,21] and prevailed from 3.0 to $2.5 \mathrm{Ga}$ seem to mark a relatively sharp change in the Earth's geodynamics. The long period of episodic melting in basaltic sources ended and new sources for granitoids emerged; an enriched mantle wedge and continental margin.

The occurrence of sanukitoid and crust-derived granitoids (sanukitoids formed before or at the same time as crust-derived granitoids $[3,24]$ ) indicate the formation of convergent and colliding continental margins with abundant multi-source batholiths of calc-alkaline granitoids.

Various contributions and interactions of melts and fluids from different mantle and crustal sources promoted the diversification of granitoid magmatism that account for the wide geochemical range of high-K calc-alkaline granitoids and the generation of multi-source granite batholiths such as the Bundelkhand granitoid batholith [3] by the end of the Neoarchaean. 


\subsection{Unresolved Problems in Archaean Geochemistry}

Resent research has established the existence of two coeval and contrasting end-members of TTGs, the high- and low HREE TTGs. Both types have been found in same Paleoarchaean [22] or Neoarchaean occurrences [14]. The close association of the low- and high-HREE types has been generally attributed to melting at different depths $[14,25]$, but there are also other alternatives to consider, for example, constant-depth melting of stacked crust with alternating garnet-bearing and garnet-absent domains, or perhaps an inheritance from garnet-fractionated mantle peridotite.

Another important unresolved question is the origin of the high K-Ba-Sr-P signature in the Mesoto Neoarchaean enriched mantle. It has been suggested that the mantle wedge probably underwent more than one phase of metasomatism related to subduction and/or low-degree melting of the mantle in association with carbonatite melts or $\mathrm{CO}_{2}$ fluids that are highly enriched in incompatible elements, especially Ba and Sr [14].

Resolving the origin and evaluating the proportions of high- and low-HREE TTGs throughout the Archaean, or detecting the origin of the high K-Ba-Sr-P signature in the Meso- to Neoarchaean mantle, are far beyond the scope of this paper. However, it is important to note that the occurrence of the highand low-HREE TTG end-members is not time-dependent; they exist from Eoarchaean to Neoarchaean and are found intermingled even within the same occurrence. On the contrary, the high K-Ba-Sr-P signature is time-dependent and appears in the Mesoarchaean for the first time. Obviously, there is a need to profoundly understand the HREE variation of TTGs and the origin of the high K-Mg-Ba-Sr-P signature, especially the source of $\mathrm{Ba}$ and $\mathrm{Sr}$, of the sanukitoids before concluding geodynamic changes in the Archaean.

\section{Conclusions}

1. In the Eoarchaean (4.0-3.6 Ga), sodic TTGs were formed mainly by episodic melting within thin or thickened basaltic oceanic crust.

2. Paleoarchaean (3.6-3.2 Ga) crustal growth was characterized by episodic TTG formation, generation of low-K calc-alkaline diorites from the mantle, and intracrustal recycling that caused thickening of the continental crust. Intracrustal melting of pre-existing crust produced crust-derived granitoids similar to their Neoarchaean counterparts.

3. A significant change in the geodynamics of Earth started in the Mesoarchaean (3.2-2.8 Ga) by the appearance of sanukitoid granitoids (high K-Mg-Ba-Sr-P and LREE) at 3.0 Ga. Sanukitoids originated in an enriched mantle wedge and reflect late-orogenic extensional tectonics. The appearance of enriched mantle signature in sanukitoid granitoids may indicate the onset of modern-style subduction.

4. In the Neoarchaean (2.8-2.5 Ga), the production of voluminous TTGs gradually ceased and abundant high-K calc-alkaline magmatism increased, indicating a significant progressive geodynamic change between 3.0-2.5 Ga from stagnant lid/plume/arc tectonics towards modern-style plate tectonics with subduction zones and mantle wedges. Abundant multi-source batholiths involving both mantle- and crust-derived material were formed at convergent and colliding continental margins, possibly indicating an assembly of a supercraton(s) towards the Archaean-Proterozoic boundary.

Supplementary Materials: The following are available online at http:/ /www.mdpi.com/2076-3263/8/9/353/s1, Table S1: Major and trace element data and ages of selected Eoarchaean to Neoarchaean granitoids.

Funding: This research received no external funding.

Acknowledgments: The K.H. Renlund foundation, Finland, is thanked for indirect support for this work. The two reviewers are greatly acknowledged and appreciated for their excellent and constructive comments.

Conflicts of Interest: The author declare no conflict of interest. 


\section{References}

1. Bédard, J.H. Stagnant lids and mantle overturns: Implications for Archaean tectonics, magmagenesis, crustal growth, mantle evolution, and the start of plate tectonics. GSF 2018, 9, 19-49. [CrossRef]

2. Hawkesworth, C.J.; Cawood, P.A.; Dhuime, B.; Kemp, T.I.S. Earth's Continental Lithosphere through Time. Annu. Rev. Earth Planet Sci. 2017, 45, 169-198. [CrossRef]

3. Joshi, K.B.; Bhattacharjee, J.; Rai, G.; Halla, J.; Ahmad, T.; Kurhila, M.; Heilimo, E.; Choudhary, A.K. The diversification of granitoids and plate tectonic implications at the Archaean-Proterozoic boundary in the Bundelkhand Craton, Central India. In Crust-Mantle Interactions and Granitoid Diversification: Insights from Archaean Cratons; Halla, J., Whitehouse, M.J., Ahmad, T., Bagai, Z., Eds.; Geological Society: London, UK, 2017; pp. 123-149.

4. Halla, J.; Whitehouse, M.J.; Ahmad, T.; Bagai, Z. Archaean granitoids: An overview and significance from a tectonic perspective. In Crust-Mantle Interactions and Granitoid Diversification: Insights from Archaean Cratons; Halla, J., Whitehouse, M.J., Ahmad, T., Bagai, Z., Eds.; Geological Society: London, UK, 2017; pp. 1-18.

5. Laurent, O.; Martin, H.; Moyen, J.-F.; Doucelance, R. The diversity and evolution of late-Archean granitoids: Evidence for the onset of "modern-style" plate tectonics between 3.0 and 2.5 Ga. Lithos 2014, 205, 208-235. [CrossRef]

6. Moyen, J.-F.; Laurent, O. Archaean tectonic systems: A view from igneous rocks. Lithos 2018, 302-203, 99-125. [CrossRef]

7. Reimink, J.R.; Chacko, T.; Stern, R.A.; Heaman, L.M. The birth of a cratonic nucleus: Lithochemical evolution of the 4.02-2.94 Ga Acasta Gneiss Complex. Precambrian Res. 2016, 281, 453-472. [CrossRef]

8. Hoffmann, J.E.; Nagel, T.J.; Münker, C.; Næraa, T. Constraining the process of Eoarchean TTG formation in the Itsaq Gneiss Complex, southern West Greenland. Earth Planet Sci. Lett. 2014, 388, 374-386. [CrossRef]

9. Wang, Y.-F.; Li, X.-H.; Wei, J.; Zhang, J.-H. Eoarchean ultra-depleted mantle domains inferred from ca. 3.81 Ga Anshan trondhjemitic gneisses, North China Craton. Precambrian Res. 2015, 263, 88-107. [CrossRef]

10. Hoffmann, J.E.; Kröner, A.; Hegner, E.; Viehmann, S.; Xie, H.; Iaccheri, L.M.; Schneider, K.P.; Hofmann, A.; Wong, J.; Geng, H.; Yang, J. Source composition, fractional crystallization and magma mixing processes in the 3.48-3.43 Ga Tsawela tonalite suite (Ancient Gneiss Complex, Swaziland)—Implications for Palaeoarchaean geodynamics. Precambrian Res. 2016, 276, 43-66. [CrossRef]

11. Dey, S.; Topno, A.; Liu, Y.; Zong, K. Generation and evolution of Palaeoarchaean continental crust in the central part of the Singhbhum craton, eastern India. Precambrian Res. 2017, 298, 268-291. [CrossRef]

12. Qiu, X.-F.; Ling, W.-L.; Liu, X.-M.; Lu, S.-S.; Jiang, T.; Wei, Y.-X.; Peng, L.-H.; Tan, J.-J. Evolution of the Archean continental crust in the nucleus of the Yangtze block: Evidence from geochemistry of 3.0 Ga TTG gneisses in the Kongling high-grade metamorphic terrane, South China. J. Asian Earth Sci. 2018, 154, 149-161. [CrossRef]

13. Oliveira, M.A.; Dall'Agnol, R.; Althoff, F.J.; Leite, A.A.S. Mesoarchean sanukitoid rocks of the Rio Maria Granite-Greenstone Terrane, Amazonian craton, Brazil. J. South Am. Earth Sci. 2009, 27, 146-160. [CrossRef]

14. Halla, J.; van Hunen, J.; Heilimo, E.; Hölttä, P. Geochemical and numerical constraints on Neoarchean plate tectonics. Precambrian Res. 2009, 174, 155-162. [CrossRef]

15. Rudnick, R.L.; Gao, S. Composition of the continental crust. In The Crust; Holland, H.D., Turekian, K.K., Eds.; Elsevier: Amsterdam, The Netherlands, 2003; pp. 1-64.

16. Reimink, J.R.; Chacko, T.; Stern, R.A.; Heaman, L.M. Earth's earliest evolved crust generated in an Iceland-like setting. Nat. Geosci. 2014, 7, 529-533. [CrossRef]

17. Reimink, J.R.; Chacko, T.; Carslon, R.W.; Shirey, S.B.; Liu, J.; Stern, R.A.; Bauer, A.M.; Pearson, D.G.; Heaman, L.M. Petrogenesis and tectonics of the Acasta Gneiss Complex derived from integrated petrology, ${ }^{142} \mathrm{Nd}$, and ${ }^{182} \mathrm{~W}$ extinct nuclide-geochemistry. Earth Planet Sci. Lett 2018, 494, 12-22. [CrossRef]

18. Rollinson, H. New models for the genesis of plagiogranites in the Oman ophiolite. Lithos 2009, 112, 603-614. [CrossRef]

19. Fisher, C.M.; Vervoort, J.D. Using the magmatic record to constrain the growth of continental crust-The Eoarchean zircon Hf record of Greenland. Earth Planet Sci. Lett 2018, 488, 79-91. [CrossRef]

20. Condie, K.C.; Puetz, S.J.; Davaille, A. Episodic crustal production before 2.7 Ga. Precambrian Res. 2018, 312, 16-22. [CrossRef] 
21. Smithies, R.H.; Champion, D.C. The Archaean high-Mg diorite suite: Links to tonalite-trondhjemitegranodiorite magmatism and implications for early Archaean crustal growth. J. Petrol. 2000, 41, 1653-1671. [CrossRef]

22. Mitra, A.; Dey, S. Occurrence of Two Different Types of Paleoarchean TTGs in Singhbhum craton, Eastern India: Insight from Geochemistry and Zircon Saturation Thermometry. In Proceedings of the American Geophysical Union, Fall Meeting 2017, New Orleans, LA, USA, 11-15 December 2017.

23. Frost, C.D.; McLaughlin, J.F.; Frost, B.R.; Fanning, C.M.; Swapp, S.M.; Kruckenberg, S.C.; Gonzalez, J. Hadean origins of Paleoarchean continental crust in the central Wyoming Province. GSA Bull. 2017, 129, 259-280. [CrossRef]

24. Heilimo, E.; Halla, J.; Huhma, H. Single-grain zircon U-Pb age constraints of the western and eastern sanukitoid zones in the Finnish part of the Karelian Province. Lithos 2011, 121, 87-99. [CrossRef]

25. Moyen, J.F. The composite Archean grey gneisses: Petrological significance, and evidence for a non-unique tectonic setting for Archaean crustal growth. Lithos 2011, 123, 21-36. [CrossRef]

(C) 2018 by the author. Licensee MDPI, Basel, Switzerland. This article is an open access article distributed under the terms and conditions of the Creative Commons Attribution (CC BY) license (http:/ / creativecommons.org/licenses/by/4.0/). 